\title{
Prominent need to increase the level of education and awareness in the field of terrorist activities
}

\section{Necesidad destacada de aumentar el nivel de educación y conciencia en el ámbito de las actividades terroristas}

\author{
Airat Halitovich Tukhvatullin \\ Kazan Federal University, Candidate of Historical Sciences, Associate Professor, Department of \\ Historical and Social Studies Education, Institute of International Relations \\ ORCID ID: http://orcid.org/0000-0001-6042-5711 \\ Vitaly Anatolievich Epshteyn \\ Russian Presidential Academy of National Economy and Public Administration, (RANEPA, \\ Moscow), PhD in Sociology, Associate Professor, Department of World Economy and \\ International Relations, Institute of Business and Business Administration \\ ORCID ID: http://orcid.org/0000-0001-7308-3351
}

Received 09-08-20 Revised 10-10-20

Accepted 20-12-21 On line 03-17-21

* Correspondence

Email: tayrat@mail.ru 


\section{Summary}

The relevance of the problem under study stems from the fact that the practice of terrorism is one of the main challenges of contemporary world politics, affecting various regions of our planet. In this regard, the study of this phenomenon within a particular region deserves special attention, Northern Ireland in this case. The practice of terrorism there has been a destabilising challenge almost throughout the twentieth century and is associated with unresolved interethnic and interreligious problems. The aim of the paper is to identify factors in the emergence, spread and de-escalation of political violence in Northern Ireland in a historical retrospective. The main approaches to the study of the problem in question are historical and analytical methods. The study shows the main reasons for the emergence and escalation of political violence and terrorism in Northern Ireland and indicates the main measures to find compromise in a multi-confessional and multi-ethnic society, which may be a model for the resolution of similar conflicts in other regions of the modern world. The materials of the paper can help to study the specifics of regional terrorism, to identify the main factors that allow reducing the level of social conflict, and to understand similar phenomena in other regions (the Balkan Peninsula, the Middle East, etc.). Moreover, it reveals the needs to make the awareness of the educated class of the society.

Key words: political violence, terrorism, Irish Republican Army, home rule, educated class

\section{Resumen}

La relevancia del problema en estudio se deriva de que la práctica del terrorismo es uno de los principales desafíos de la política mundial contemporánea, afectando a diversas regiones de nuestro planeta. En este sentido, el estudio de este fenómeno dentro de una región en particular merece una atención especial, Irlanda del Norte en este caso. La práctica del terrorismo ha sido un desafío desestabilizador durante casi todo el siglo XX y está asociada con problemas interétnicos e interreligiosos no resueltos. El objetivo del artículo es identificar los factores del surgimiento, propagación y desescalada de la violencia política en Irlanda del Norte en una retrospectiva histórica. Los principales enfoques para el estudio del problema en cuestión son los métodos históricos y analíticos. El estudio muestra las principales razones del surgimiento y escalada de la violencia política y el terrorismo en Irlanda del Norte e indica las principales medidas para encontrar un compromiso en una sociedad multiconfesional y multiétnica, que puede ser un modelo para la resolución de conflictos similares en otras regiones del mundo moderno. Los materiales del trabajo pueden ayudar a estudiar las especificidades del terrorismo regional, a identificar los principales factores que permiten reducir el nivel de conflicto social y a comprender fenómenos similares en otras regiones (Península Balcánica, Oriente Medio, etc.). Además, revela las necesidades de concienciar a la clase educada de la sociedad.

Palabras clave: violencia política, terrorismo, ejército republicano irlandés, autonomía, clase educada

\section{Introduction}

The conflict in Northern Ireland is the longest and bloodiest confrontation, maybe comparable only to the Arab-Israeli conflict in terms of passion and number of victims.

In British political circles, October 2018 marked a fiftieth anniversary of official London's strained relationship with its recalcitrant territories in Northern Ireland. This is due to the fact that in 1968 there were serious clashes in the Northern Irish city of Londonderry, which then spread to Belfast, the capital of Ulster. 
The history of the confrontation goes back to the XI-XII centuries, when the invading Normans, descendants of William the Conqueror, with expanding their possessions, began to lay territorial claims to the "emerald" island (the ancient name of Ireland). In 1171, after a series of bloody battles, the Norman king of England, Henry II Plantagenet (1154-1189), took control of Ireland. The English barons seized the southeastern lands of Ireland and turned them into a bridgehead for further raids and conquests. This fortified area was called 'Pale', meaning 'an enclosed place'. Since then clashes between the Normans and the Irish have not led to any major new battles, as the conquerors could not maintain a regular army to rule the Irish peasants and the local population lacked the strength and resources to attack the small Norman force sheltering in the well-fortified castles.

The situation thus stabilised until the sixteenth century, when the English King Henry VIII (1509-1547), who in 1541 took on the title of King of Ireland wished to free himself from the ecclesiastical chains of Catholic Rome, carried out the Protestant Reformation, and established the independent Church of England. He made efforts to create such an independent church in Ireland, but the Irish Catholics who had converted to Christianity in the V century, could not tolerate such a step and began rebellions against the king of England.

Problems between Irish Catholics and Protestants deepened during the reign of Henry VIII's daughter, Elizabeth I (1558-1603), whose government seized vast areas of 1300,000 acres during the suppression of the Ulster uprising and incorporated these more fertile agricultural regions in the north of the island into a separate district. The new lands begin to be given to English nobles for further colonisation. Thus the colony of Ulster was created and English and Scottish Protestants established themselves in the new territory, displacing many of the original Irish settlers or turning them into petty tenants (Abramson et al., 1986). As a result, ethnic divisions developed in Ireland, fuelled by religious differences and economic strife, causing periodic riots and rebellions that lasted until the second half of the 20th century.

\section{Methods}

This paper uses such methods as historical-comparative and analytical research on socio-political processes in Northern Ireland. The objective basis for historical comparisons is that the sociohistorical development of any process, including terrorism, is a natural process. Many of its phenomena are identical in their inner essence and differ only in territorial and chronological variation of forms, and the same similar manifestations can express different contents. Due to this, the process of comparison provides an opportunity to explain the facts in question and to reveal the essence of the processes under study.

On the other hand, the historical-comparative method makes it possible to go beyond the phenomena under study and arrive at broad historical generalisations and parallels on the basis of analogies, which is complemented by the analytical method of research. This method considers a set of factors affecting the object of study, identifying major and minor, temporary and persistent, explicit and latent (hidden), controllable and uncontrollable among them.

\section{Results and Discussion}

One of the researchers of the Irish conflict, J. Costigan, believes that the main sources of irritation of the local Catholic population in the seventeenth century were:

a) The systematic eviction of Irish peasants from the colony territory of Ulster and their resulting poverty, starvation and increased mortality of the local population;

b) The brutal suppression of Catholic discontent (Oliver Cromwell excelled in this, personally having led a punitive expedition in 1649-1652, "subdued" the Irish who had rebelled in 1641 and massacred thousands of Catholics) (Costigan, 1980). 
Another aggravation of relations between Catholics and Protestants occurred between 1689 and 1691, when James II Stuart deposed in a coup d'état in 1688, used Ireland as a base for war against William III of Orange, the new English king. In August 1689 Irish Protestant skilled labourers calling themselves 'apprentice boys' were freed by the English after defending Derry during a long siege by troops of the Catholic pretender to the throne. The following year William of Orange defeated James II's forces at the Battle of the Boyne River. The events of this clash have been sung every year since 1690 until today by Protestants in celebrations, parades and demonstrations by the so-called 'Orange Order'. These processions annually recall the memory of the people of Northern Ireland, reviving the events of long ago and demonstrating the still present divisions between Protestants and Catholics.

The 18th and early 19th centuries were characterised by periods of rebellion, famine, and emigration. Irish nationalists repeatedly dared to challenge the English authorities, but were always defeated by them.

Among the most famous leaders there was Thomas Wolfe Tone, who led a rebellion based on Irish nationalism from 1796 to 1798 . He tried to appeal to both Protestants and Catholics in the hope of forming a united front against the Great Britain. Wolf Tone argued that Irish independence was more important than religious differences. In the end, his rebellion failed, thus showing the superiority of religious differences over ideas of national unity.

At the end of the eighteenth century, Protestants and Catholics began to form their own paramilitary organisations. Being divergent in their religious beliefs, these initially defensive organisations began to confront each other violently. It was during this period that the famous "Orange Orders" emerged. Taking their name from William of Orange, these Protestant organisations aimed to maintain union with the Great Britain. The "Orange" Lodges soon grew so large that they began to dominate the political and social life of the north of Ireland.

In 1801 the British Parliament approved the Union Act, designed to incorporate Ireland into the Great Britain. The struggle surrounding this Act began to dominate Irish politics. Unionists, primarily 'Orangeists' in the north, supported the Act, while Republicans, who became known as 'Greens', argued in favour of constitutional government and an independent republic of Ireland. Daniel O'Connell led the republican movement in the early nineteenth century, and Charles Stewart Parnell, a Protestant, created the Democratic Irish Party in the late nineteenth century to support the cause.

Ireland experienced several famines in the eighteenth century as the peasants suffered from little land, were poor, and susceptible to natural disasters (Titova et al., 2019). The bad harvest of 1845 and the resulting famine of 1845-1848 devastated Ireland as never before. Its impact was felt most strongly among the poor, especially among Irish Catholics. Therefore, at a time when other industrial nations were experiencing a numerical increase in population, in Ireland the population shrank by a quarter. As hunger and disease persisted, thousands of Irish emigrated to other parts of the world (mainly America, Australia, Canada, and New Zealand). It was during this period that the Unionists in the north strengthened their link with Ulster.

For several years after the famine, some members of the British Parliament sought to free Ireland from British rule. But all attempts to consider self-government laws for Ireland were fiercely resisted by Unionists and British military circles. The Unionists, who mainly included Protestant skilled workers, industrialists and landowners in the north, feared that self-government would change the balance of economic power in the north. They believed that continued union with Britain was their only choice for economic prosperity. 
Thus the religious aspect of the conflict persisted and was exacerbated by deep economic disagreements. In this regard, mention should be made of the Volga region of Russia, where representatives of different faiths have lived on the same territory for centuries, but conflicts on religious grounds have hardly occurred over the last three hundred years (Titova et al., 2019).

There is another aspect of conflict that should be emphasized. Already by the 19th century both the republicans and the majority of unionists were fully Irish. This meant that neither side included immigrants from other countries. The Unionist Protestants in the north had lived in Ireland for generations and were as Irish as their Catholic opponents.

J. Costigan, who has already been mentioned, believed that the Republicans' idea of a military solution to the Irish conflict was born in New York in 1857. Irish Catholics emigrated, but never forgot those who remained in their homeland. Irish immigrants in New York formed the Irish Republican Brotherhood (IRB), an organisation to provide financial assistance to relatives back home. After the American Civil War, some Irish soldiers having gained combat experience by returning from the federal army, decided to start fighting for the liberation of Ireland. The IRB gradually developed into a revolutionary organisation.

By 1916 the situation in Ireland had changed. The British promised Irish self-government when the First World War would be over. While most people in Ireland seemed to believe the British, Unionists and Republicans were secretly arming themselves for a civil war between the North and the South. They believed that a fight was inevitable if the British recognised selfgovernment and each side would seek to control the governance of a newly independent Ireland. And some forces were unwilling to wait for recognition of self-government.

Thus, seeing the British focus on Germany, the IRB leaders decided that the time had come for a strike against the Unionists and their British supporters. And during Easter 1916, Patrick Pearse and James Connolly led a rebellion in Dublin.

The uprising was a local success as it proved a complete surprise to the British. Pearse and Connolly, with several thousand their armed followers, took control of several important points in Dublin. In the hall of the city's main post office, Patrick Pearce proclaimed the Irish Republic. The British government regarded the Irish actions as betrayal in the midst of war and sent troops into Dublin.

A few days later the city was devastated by British artillery. Realising the hopelessness of the situation, Pearse entered into negotiations with the British and began requesting an armistice by sending a message using a new title as his signature: 'From the General in Command of the Irish Republican Army to the General in Command of the British Armed Forces'. This is how the IRB transformed itself into an army: the IRA.

The British crushed the rebellion and many republicans were executed and thousands sentenced to imprisonment; the promised self-government seemed to be forgotten. Most Irish were shocked by such a harsh reaction from London. In response to the brutality of the army, many young Catholic Irishmen began to join the IRA, which was led by Michael Collins at the end of the First World War. The IRA under his leadership continued its campaign of violence against Unionists and the RIC. The British responded by sending hastily recruited armed forces the so-called 'Blacks' and 'Bronzes', named for their uniforms - and Ireland became the scene of a bloody war. Each opposing side accused the other of villainy, but murder and violence were tactics of both.

In 1921, the situation was temporarily resolved by an agreement between England and Ireland, under which Ireland was given independence, while the northern area around Ulster remained under British protection until its peaceful incorporation into Ireland was possible. Although most people in Ireland, including M. Collins, welcomed the agreement, the violence could not be ended as the IRA rejected this 'half-hearted' solution. 
The IRA now fought against government forces, demanding that Irish independence should be extended to all Irish people, but the organisation was divided. Its political weight was sharply reduced following the withdrawal of some leading members and a campaign of arrests.

While the British not intervening in the peculiar civil war in the southern regions of the island, they strengthened their connection with Northern Ireland and supported its forces with a new police force, the Royal Ulster Constabulary, or RUC. The Northern Unionists were pleased when the British installed a semi-autonomous government in Northern Ireland and gave it special powers to fight the IRA. The Unionists used this power to gain control of Northern Ireland and come under British influence. Thus Ireland became a divided country.

By the 1930s, two trends had emerged in the IRA. Supporters of the first believed that Irish republicanism could be expressed through peaceful political idealism and chose to follow the leadership of their political party, Sinn Féin. Supporters of the second declared that they would never be at peace with the British or Unionists until the North was united with the South, and vowed to continue their struggle. Thus the Provisional Irish Republican Army (PIRA) has emerged; it was responsible for the terrorist campaign in Northern Ireland from 1956 to 1962. Although the PIRA initially enjoyed support among the Catholic enclaves in the North, most Irish people, Unionists and republicans alike, were dismayed by the new round of violence. So soon even the 'official' IRA began to criticise the terrorist attacks of the 'provisional'.

Eventually, having faced with a lack of public support, the PIRA stopped almost all activities by 1962. Some of the Provisionalists joined the civil rights movement; others were in opposition to their former colleagues in the "official wing", while most stayed in the classified infrastructure and waited for the moment when the organisation's numbers and prestige could be restored.

By 1969 , the civil rights movement and the reaction to it had intensified. The government began to harshly suppress and disperse any demonstration by Catholic Irish demonstrators for their civil rights, even demonstrations for better housing and education. M. Hastings wrote that the peaceful aspiration to fight for equal rights was cornered by Northern Irish militancy (Bell, 1974). As some researchers believe, it is true that this negative attitude towards Irish Catholics by the British government was due to old grievances, such as the fact that Ireland did not officially enter the Second World War, once leaving England alone with Hitler's Germany (Hastings, 1970).

Be that as it may, the problem of the relationship between the two religious groups reached a decisive stage in the summer of 1969. The civil rights demonstrators had planned a long, peaceful march from Londonderry to Belfast but were attacked with tear gas and dispersed by the RUC and the reserve forces (B-Specials). On 15 August, 1969, protestors gathered for the traditional 'apprentice boys' festival. Only a few days earlier, the RUC vigorously dispersed Catholic demonstrators, now it welcomed Protestant columns. The Catholics were not surprised: many B-Specials took off their uniforms to march alongside the Protestants, dressed in Orange robes.

Protestant demonstrators in Londonderry and Belfast armed themselves with Molotov cocktails, stones, and sticks. They were not only seeking to commemorate the 17th century events, but, encouraged by the recent crackdown on Catholic demonstrators, they wanted to reinforce their position by attacking Catholic neighbourhoods during the march. Many politicians and journalists argued that the march should be banned, but the authorities did not. As a result, violence was broken out in Catholic neighbourhoods during the march. Dozens of people were killed and hundreds more were injured. Belfast and Londonderry were engulfed in flames. In 
Belfast alone, about 60,000 people were left homeless during this time. The unrest spread in many other towns (Brennok, 1996).

Three days later, the British government sent an army into Northern Ireland as a peacekeeping force. The troops were greeted favourably by all parties to the conflict: the Unionists believed that the army would help clamp down on the Catholics, and the Republicans believed that the army would protect them from the Unionists and the police.

According to B. Bell and a number of other researchers it was the British Army's policies that led to the revival of the IRA. This is because the troops arrived in Ulster with little or no knowledge of the historical circumstances surrounding the conflict. The officers thought they were in the middle of a colonial war. They misjudged the situation and thought that there were two opposing sides, one fighting under the Irish tricolour banner, while the other stood under the national flag of the United Kingdom and claimed to represent the patriots of the British Empire. That is why the army allied itself with those who called themselves national patriots.

This policy was a fatal mistake, as the conflict in question was far from a struggle to maintain British influence in the colony: the struggle in Northern Ireland was a conflict between two groups of Irish citizens. Neither side was 'British', regardless of what their slogans and banners demanded. The army was supposed to be a peaceful, neutral force, but it mistakenly allied itself directly with one of the extremist sides in the conflict. This mistake led to the resurgence of the IRA.

In August 1968, severe unrest began in Londonderry and affected Belfast, the capital of Northern Ireland. Following the arrest and imprisonment of popular Irish civil rights activist Bernadette Devlin, clashes resumed in June 1970.

When the situation reached its critical point, the Northern Ireland administration turned to the British government, which sent additional troops to the region. After a series of ill-conceived and drastic measures, such as allowing activity of the Inspector General in the Royal Ulster Constabulary, which was then disarmed, the situation escalated again.

In January 1972, Londonderry made it felt once again, when local Catholics, ignoring the ban on demonstrations, came out in an annual demonstration which was violently dispersed by British troops. The result was the establishment of direct rule by the British parliament and government until a referendum on the self-determination of the region was held.

In March 1973, a referendum was held on whether Northern Ireland would remain part of the United Kingdom or become part of the Republic of Ireland. This plebiscite was ignored by the majority of Catholics, who believed that the results would be in favour of the Protestants. The referendum resulted in a bill that Northern Ireland would not be separated from the Great Britain without the consent of the majority of the population.

A parliament was established, and then it was dissolved indefinitely and direct rule from London was introduced in 1976 following a new aggravation of the situation. This led again to an expansion of the terrorist attacks that shook the region in the second half of the 1970s and in the 1980s.

A convergence began in the mid-1990s. In the summer of 1997, President Adams of the Sinn Féin managed to persuade the IRA's radical wing leaders to stop terrorist activities and take part in peace talks. A compromise was reached in 1998 whereby Northern Ireland remained part of the United Kingdom and the Republic of Ireland renounced its territorial claims in the region. As V.T. Sakaev notes, the situation in such regions can also be complicated by migration processes, alongside territorial claims (Sakaev, 2018).

\section{Summary}


B. Bell believes that the first campaign of violence, terrorist bombings and assassinations supported by the IRB took place between 1870 and 1916. The immediate targets of the attacks were Unionists and forces in Britain supporting the Unionist cause. One of their most important opponents was the British-backed police force in Ireland, the Royal Irish Constabulary, or RIC (Bell,1976).

From 1922 to 1966, the British government systematically reduced the civil rights of Catholics in Northern Ireland and increased the political and economic influence of the Unionists. According to A. Lee's research, the emergence of the civil rights movement among Catholics in the post-war period can be explained by these very reasons. Initially the civil rights movement was supported by both Protestants and Catholics, but the actions of the British government in Northern Ireland began to inflame the problem by framing it as a republican-Unionist confrontation. As a result, Unionists began to see the Catholic movement as a force seeking to redistribute economic and political benefits (Lee,1983).

Feeling oppressed at all sides, Catholics and Republicans began to seek help, and they found it in the form of the IRA. "Officials" and "provisionals", still divided during the 1969 riots, put aside internal contradictions, and focused on a new common enemy, the British army. Since then, the new IRA policy has emphasised the removal of British soldiers from Irish soil and has brushed aside internal political differences within its ranks.

Subsequent events have shown that pressure by force only leads to increased confrontation between official London and the Catholic part of Ulster. A compromise was not reached until the mid-1990s, but even then the clashes continued, culminating in the town of Oma on 15 August 1998, which killed 29 people and injured more than 200.

In May 2000, London ended its policy of direct rule over Northern Ireland and power was partially transferred to Stormont, the Northern Ireland Legislative Assembly. The IRA was officially dissolved in 2005, but the region remains potentially dangerous, aided by the Brexit process (Britain's exit from the EU), which could lead to new economic problems and a flare-up of social problems that could lead to a new escalation of violence.

\section{Conclusions}

Violent confrontation in Northern Ireland has a long history and is an example of the transition from mass action to a terrorist method of struggle. The acuteness of these processes is related not only to historical grievances, but also to objective religious and ethnic conflicts.

The peculiarity of the events in Ulster is also important for analysis because it shows the fragility of the boundaries between the concepts of "national freedom fighter" and "terrorist", which can become an object of manipulation by the parties involved in the conflict.

Ireland was historically the first English colony to be invaded from the twelfth to the sixteenth centuries. After the First World War, Ireland achieved independence in 1921, but the six counties in Northern Ireland (Ulster) remained part of Great Britain with extensive autonomy. Until 1973; the region had a federal relationship with the British parliament and it had its own legislature, Stormont, which had a wide range of powers.

The heart-breaking conflict in Northern Ireland from 1968-69 is all too often portrayed by the media as a religious war between Catholics and Protestants, whereas the problem is primarily the colonisation of Ireland by England (Giffan, 2020). 
From 1968 a serious confessional situation began to escalate between Protestants who were loyal to the British authorities and Catholics who favoured reunification with the rest of Ireland. Paramilitary groups were being formed; the most active were the nationalist Irish Republican Army (IRA) and the loyalist Ulster Defence Association and the Ulster Voluntary Service. As a result, the British government is sending additional army units to the region, leading to an escalation of violence, including an increase in terrorist attacks.

The lessons of Northern Ireland are clear. Almost four decades of confrontation in Ulster show the futility of terrorist methods of fighting for civil rights. The loss of funding sources drastically reduces the intensity of terrorist attacks. When the population chooses to live peacefully, militants begin to recruit among unsophisticated teenagers, as we see now in the North Caucasus. Establishing peace in a hotspot is a long and painstaking process (Myasnikov, 2007). As G. Pashayeva notes, despite the difficulties in finding a comprehensive political solution to the protracted ethno-territorial conflict in Northern Ireland, on the whole, there is every reason to believe that the main problems have been left behind (Pashaeva, 2014).

Thus, it should be noted that the origins of terrorism in the region are a combination of socio-economic, confessional, and ethnic problems. The experience of improvement in Northern Ireland is an important model for resolving similar conflicts in other regions of Europe.

\section{Acknowledgements}

The work is performed according to the Russian Government Program of Competitive Growth of Kazan Federal University.

\section{References}

Abramson, M.L., Kirillova, A.A., Kolesnitsky, N.F. et al. (1986). Edited by N.F. Kolesnitsky. History of the Middle Ages: a textbook for students of historical faculties of pedagogical institutes / - 2nd ed. corrected and amended. - M.: Prosvetchenie.

Bell, B. (1974). The Secret Army: A History of the IRA, 1916-1970. - Cambridge: MIT Press.

Bell, B. (1976). Strategy, "Tactics, and Terror: An Irish Perspective". International Terrorism. New York: Praeger.

Brennok, M. (1996). There is a trefoil growing in the meadows. Europe, 4(27) July-August. -

Costigan, G.A. (1980). "History of Modern Ireland". - Indianapolis: Bobbs-Merrill.

Giffan, J. (2020). Northern Ireland: The Walls Say. “Ar Men” (Stone) No. 76 April 1996.http: //www.breizh.ru/research/ulster.htm (accessed 10.05. 2020).

Hastings, M. (1970). Barricades in Belfast". - New York: Taplinger.

Lee, A. (1983). Terrorism in Northern Ireland". - New York: General Hall.

Myasnikov, V. (2007). The operation in Ulster is over". Novaya Gazeta. 08/10/2007.

Pashaeva, G. (2014). The role of official diplomacy and external actors in resolving the conflict in Northern Ireland". Analyticon, July.

Sakaev, V.T. (2018). Risks of the High-Scale Immigration in the Public Discourse of Russia. Revista San Gregorio, 23, 92-98

Titova, T., Frolova, E., Gushchina, E., \& Blagoveshchenskaya, A. (2019). Confessional groups in the Republic of Tatarstan: identity and features of its design. Codrul Cosminului, 25(1), $87-95$. 